Noticias 


\title{
XIV Coloquio Internacional de Hermenéutica Analógica
}

\section{International Colloquium of Analogical Hermeneutics}

\author{
Aldo Camacho \\ aldoalejandrocamacho@gmail.com \\ Claudia González \\ claudia.gonzalez.perez@gmail.com
}

Del 9 al 12 de octubre de 2018 se celebró el XIV Coloquio Internacional de Hermenéutica Analógica, en la Sala José Gaos del Instituto de Investigaciones Filosóficas y en el Aula Magna de la Facultad de Filosofía y Letras, ambas de la UNAM. En esta ocasión el doctor Juan R. Coca, profesor e investigador de la Universidad de Valladolid (España), fue nuestro invitado especial. En su conferencia magistral: "El pilar analógico de la sociohermenéutica multidimensional", hizo un análisis comparativo - desde la fenomenología y la hermenéutica analógica- de las costumbres de la sociedad a partir de su estructura multicultural; de este modo, según Coca, desde la hermenéutica analógica se abriría una comprensión interpersonal entre las culturas que conviven, así como una gama enor- me de costumbres éticas y políticas que darían paso a la formación o estructura de una sociedad común entre varias sociedades. En contraste, desde la fenomenología, no resulta suficiente integrar a las distintas sociedades bajo un mismo análisis descriptivo, ya que cada sociedad tiene diversas costumbres y esto produce que tengan intencionalidades distantes.

Contamos con otras tres conferencias magistrales, impartidas por los doctores Ambrosio Velasco, Manuel Lavaniegos y Carlos Oliva.

En su conferencia "Hermenéutica analógica y filosofía mexicana”, Ambrosio Velasco mostró la importancia de la propuesta de Mauricio Beuchot en el contexto filosófico de nuestro país. Hizo un recuento de los "momentos analógicos" de nuestra filo- 
sofía, desde los tiempos prehispánico y novohispano hasta el contexto filosófico mexicano actual, para dar relevancia a los sentidos metafísico, ético y político de la hermenéutica analógica en la sociedad mexicana actual.

Por otra parte, Manuel Lavaniegos, en su conferencia "Crisis de la religiosidad. Historicidad y hermenéutica”, trató la relevancia del símbolo religioso desde Durand y Eliade, para rescatar la experiencia subjetiva de la religión en cierto momento y en cierta situación, en la que el sentido simbólico de la religión se convertiría en un supuesto existenciario del ser humano. De esta forma, según Lavaniegos, sería válido externar la experiencia religiosa en una suerte de intersubjetividad religiosa, con el fin de encontrar un sentido con el otro, pues la palabra símbolo se asocia a la comunión o reconocimiento del otro, algo común que une a dos personas.

La última conferencia magistral estuvo a cargo de Carlos Oliva; en "Hermenéutica y teoría crítica", el autor se centró en la interpretación de los Manuscritos económico-filosóficos y El capital, de Karl Marx. Expuso el contexto en el que Marx escribió ambos textos para dar énfasis al sentido de mercancía y fetiche de la literatura. Argumentó que los libros y la literatura caen, hasta cierto punto, en una suerte de fetichismo, cuando, ahora, escribir cualquier mensaje, por ejemplo, en las redes sociales, se convierte en un tipo de mercancía para que los otros, de manera drástica, lo lean y lo compartan. La respuesta a la pregunta por el sentido actual de los libros y de la literatura quedó abierta para Oliva, porque si bien el consumo de literatura a veces ocurre de manera impulsiva y sin un sentido que alimente un interés estético e intelectual personal, en otras ocasiones opera en ambos sentidos.

Los doctores Mario Chávez Tortolero y Gabriel Astey, acompañados de Mauricio Beuchot, nos compartieron sus saberes sobre metafísica y poesía en una charla intitulada "En torno a la metafísica poética: construcción de sentido y ejercicio de la reflexión". En ella resaltaron la importancia de la metafísica en la estética, para encontrar el sentido de la creación artística a través de la hermenéutica analógica, pues, según los participantes, el arte es ahora una gama de creaciones confusas y sin sentido, donde lo que prevalece es lo grotesco y lo impactante, donde no hay comprensión entre el arte, el artista y el público, o bien, entre la belleza, el arte y el sentido. Así, resaltaron las posturas de María Zambrano y de Gadamer para basarse en el sentido poético-metafísico del arte.

Finalmente, es importante señalar que año con año es mayor la cantidad 
de estudiantes, profesores e investigadores que participan en el Coloquio, lo que muestra que la recepción de la hermenéutica analógica crece cada vez más, no solo en México sino en otros lugares del mundo; así como su apertura a otros campos del saber, ya que contamos con mesas que la abordaron desde la filosofía, con el llamado nuevo realismo y la ética, hasta disciplinas que no son propiamente filosóficas, como la literatura, la comunicación, la historia, el derecho, el psicoanálisis, la pedagogía, el urbanismo y la sociología.

No cabe duda de que la hermenéutica analógica es una propuesta original e innovadora y que resulta una herramienta importante para llegar a una comprensión humana y prudente, pues estos tiempos reclaman comprensión y valor en situaciones llenas de violencia e incertidumbre política y moral, así como entre posturas intelectuales positivistas y posmodernas.

\section{Aldo Camacho}

Licenciado en Filosofía por la Facultad de Filosofía y Letras de la UNAM. Ha participado en los coloquios de hermenéutica analógica. Becario del doctor Mauricio Beuchot.

\section{Claudia González}

Egresada de Filosofía por la Facultad de Filosofía y Letras de la UNAM. Ha participado en los coloquios de hermenéutica analógica. Becaria del doctor Mauricio Beuchot. 